\title{
Place Bonding on Campus Interior Design ITS: Attachment and Identity
}

\author{
Susy Budi Astuti ${ }^{1}$, Friday Yaumus S. ${ }^{2}$, Lisani Husna ${ }^{3}$, Elvira Pramesvari ${ }^{4}$ \\ 1,2,3,4 Departemen Desain Interior, Fakultas Arsitektur, Desain, dan Perencanaan, ITS Surabaya \\ Jln. Raya Keputih, Sukolilo - Surabaya 60119 Telp 031.5925223 \\ ${ }^{1}$ susy@interior.its.ac.id
}

\begin{abstract}
ABSTRAK
Place bonding merupakan fenomena adanya keterikatan manusia pada suatu tempat. Place bonding dipengaruhi oleh faktor karakter aktifitas. Penelitian ini menggunakan metode kulitatif dengan pendekatan fenomenologi, dengan menggunakan kuesioner sebagai instrumen utamanya. Hasil dari penelitian ini menggambarkan bagaimana tingkat keterikatan mahasiswa Desain Interior di ITS dengan kampusnya, yang secara umum dibedakan berdasarkan tingkatan mahasiswa, kegiatan, karakteristik mahasiswa, dan fasilitas tempat yang tersedia. Hasil penelitian menunjukkan bahwa place bonding/keterikatan mahasiswa Desain Interior ITS dengan kampusnya paling dipengaruhi oleh karakter pembeda di setiap angkatan, karena pada setiap angkatan memiliki intensitas masing-masing terhadap kegiatan yang ada di dalam kampus Desain Interior.
\end{abstract}

Kata kunci: aktivitas; keterikatan; tempat

\section{ABSTRACT}

Place bonding is a phenomenon of human attachment to a place. Place bonding is influenced by character activity factors. This study uses a skinative method with a phenomenological approach, using a questionnaire as the main instrument. The results of this study illustrate how the level of attachment of Interior Design students in ITS to the campus, which is generally distinguished by the level of students, activities, characteristics of students, and available facilities. The results showed that the place bonding / ITS Interior Design students' attachment to the campus was most influenced by the distinguishing characteristics in each class, because in each class the intensity of each activity on the campus had its own intensity.

Keyword: activity; attachment; place

\section{PENDAHULUAN}

Place attachment atau place bonding sebagai identitas dan ketergantungan pada tempat mencerminkan identitas individu atau kelompok dalam kaitannya dengan lingkungan fisik” (Proshansky, 1978 dalam Qingjiu, Sun, dan Nor Zarifah Maliki, 2016). Place attachment merupakan keterikatan seseorang terhadap tempat tidak saja pada tempat yang ditinggali, namun juga pada tempat yang berhubungan dengan kehidupan sehari-hari (Lewicka, 2011 dalam Nurhijah, 2015), misalnya di sekolah, kampus, taman dan lain-lainnya.

Baskin, Wampold, Quintana, \& Enright (2010); Freeman, Anderman \& Jensen (2007); Pittman \& Richmond (2008) (dalam Nurfitriana, 2016) menggunakan berbagai istilah untuk mewakili konsep keterikatan tempat dengan perguruan tingginya. Kadang disebut dengan istilah seperti "rasa memiliki" terhadap sekolah. Breakwell (1983) dalam Qazimi (2014) berpendapat bahwa tempat adalah sumber signifikan elemen identitas. Aspek identitas tertentu yang berasal dari tempat, timbul karena tempat memiliki figur atau makna yang penting bagi penggunanya. Berdasarkan hal tersebut karakter kampus membawa dampak identitas mahasiswanya. Terjadi hubungan timbal balik antara lingkungan dan penggunanya. 
Menurut Hashemnezhad (Nurhayati, 2015 dalam Jattmiko, 2016), menggunakan istilah sense of place, yaitu sebuah keadaan dimana manusia dapat merasakan tempat secara menyeluruh, mempersepsikan diri mereka terhadap lingkungan dan memiliki keterikatan pada tempat yang memiliki arti tertentu bagi mereka. Sense of place diawali dengan sensasi yang mereka terima dari sebuah lingkungan, sensasi tersebut dapat berupa atmosfir dan kesan yang ditimbulkan kemudian dipersepsikan oleh individu, persepsi yang muncul kemudian dapat membuat sebuah makna subjektif terhadap tempat tersebut.

Kampus merupakan lembaga, tempat mengadakan kegiatan perkuliahan yang melibatkan aktivitas dosen, mahasiswa dan tenaga kependidikan. Kampus Desain Interior ITS Surabaya memiliki karakteristik khusus. Aktifitas perkuliahan sangat beragam, selain materi teori, juga ada materi studio atau workshop. Keberagaman kegiatan di kampus desain memilik makna yang spesifik. Mahasiswa desain interior selain berkegiatan terstruktur, juga melakukan aktivitas mandiri. Aktivitas mandiri berkaitan dengan sistem studio atau workshop. Hubungan timbal balik tidak hanya antara lingkungan kampus dengan mahasiswa, namun juga antar mahasiswa desain.

Penelitian ini merumuskan keterikatan mahasiswa secara akademis maupun non-akademis terhadap fasilitas lingkungan kampus desain. Fokus yang diteliti adalah tentang karakter perilaku aktifitas mahasiswa, place attachment atau place bonding, dan sign mahasiswa yang menjadi identitas keterikatan di kampus Desain Interior ITS.

\section{METODE PENELITIAN}

Penelitian ini merupakan penelitian kualitatif dengan pendekatan fenomenologi. Fenomena diamati melalui observasi kuisioner dan wawancara. Langkah awal penelitian dilakukan dengan observasi penggunaan ruang oleh mahasiswa, intensitas waktu yang digunakan mahasiswa di kampus desain, dan karakteristik penampilan mahasiswa desain. Untuk memperoleh data lengkap ke setiap angkatan mahasiswa desain, maka kuisioner dan wawancara menjadi data yang penting. Responden dilakukan 4 angkatan mahasiswa yang masih aktif yaitu angkatan 2015, 2016, 2017 dan 2018. Pada setiap angkatan terdapat 35 responden. Hal tersebut telah mewakili $70-80 \%$ jumlah mahasiswa pada setiap angkatan.

\section{HASIL PENELITIAN DAN PEMBAHASAN}

Place bonding/place attachment mahasiswa pada kampus Desain Interior ITS diamati pada jenis kegiatan yang beragam, yaitu kegiatan kelas studio, kelas mandiri, asistensi, kegiatan komunitas, kegiatan himpunan, dan kegiatan angkatan. Pengamatan dilakukan di semua sarana ruang di kampus Desain Interior ITS yaitu Gedung Workshop, Ruang 305, Ruang 306, Ruang 309, Ruang 104 (Ruang Dosen), Ruang 206 (Ruang Dosen), Ruang 308 (Ruang Baca), Ruang HIMA, Kantin, Meja Beton/Tribun 'outdoor', selasar Workshop dan Selasar Despro. Selain mengamati tentang penggunaan ruang, juga diamati tentang intensitas mahasiswa berada di kampus (Tabel 1 dan 2) serta karakteristik mahasiswa saat berada di area kampus (Tabel 3).

Tabel 1. Penggunaan Ruang Berdasarkan Perbedaan Aktivitas per Angkatan Mahasiswa

\begin{tabular}{|c|c|c|c|c|c|c|c|c|c|c|c|c|c|}
\hline \multirow{2}{*}{ NO } & \multirow{2}{*}{ KEGIATAN } & \multirow{2}{*}{ RUANG } & \multicolumn{11}{|c|}{ Mahasiswa Angkatan } \\
\hline & & & \multicolumn{3}{|c|}{2015} & \multicolumn{3}{|c|}{2016} & \multicolumn{3}{|c|}{2017} & \multicolumn{2}{|c|}{2018} \\
\hline 1 & Kegiatan Belajar Mengajar & Workshop & & $\mathrm{v}$ & & $\mathrm{v}$ & & & $\mathrm{v}$ & & & $\mathrm{v}$ & \\
\hline & & R.305 & $\mathrm{v}$ & & & & $\mathrm{v}$ & & & & & & $\mathrm{v}$ \\
\hline & & R.306 & & & $\mathrm{v}$ & & & $\mathrm{v}$ & & & $\mathrm{v}$ & & \\
\hline & & R.309 & & & & & & & & $\mathrm{v}$ & & & \\
\hline
\end{tabular}




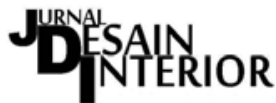

Vol. 4, No. 1, Juni 2019, pISSN 2527-2853, eISSN 2549-2985

\begin{tabular}{|c|c|c|c|c|c|c|c|c|c|c|c|c|c|c|}
\hline \multirow{2}{*}{ NO } & \multirow{2}{*}{ KEGIATAN } & \multirow{2}{*}{ RUANG } & \multicolumn{12}{|c|}{ Mahasiswa Angkatan } \\
\hline & & & \multicolumn{3}{|c|}{2015} & \multicolumn{3}{|c|}{2016} & \multicolumn{3}{|c|}{2017} & \multicolumn{3}{|c|}{2018} \\
\hline \multirow[t]{4}{*}{2.} & \multirow[t]{4}{*}{ Melakukan Asistensi } & R.206 & $\mathrm{v}$ & & & & & & & $\mathrm{v}$ & & & $\mathrm{v}$ & \\
\hline & & R.104 & & $\mathrm{v}$ & & $\mathrm{v}$ & & & $\mathrm{v}$ & & & $\mathrm{v}$ & & \\
\hline & & R. 309 & & & & & & $\mathrm{v}$ & & & $\mathrm{v}$ & & & \\
\hline & & workshop & & & $\mathrm{v}$ & & $\mathrm{v}$ & & & $\mathrm{v}$ & & & & $\mathrm{v}$ \\
\hline \multirow[t]{3}{*}{3.} & \multirow[t]{3}{*}{ Mengumpulkan Tugas } & workshop & & & $\mathrm{v}$ & & & $\mathrm{v}$ & & & $\mathrm{v}$ & & & $\mathrm{v}$ \\
\hline & & R.104 & & $\mathrm{v}$ & & & $\mathrm{v}$ & & $\mathrm{v}$ & & & $\mathrm{v}$ & & \\
\hline & & R.206 & $\mathrm{v}$ & & & $\mathrm{v}$ & & & & $\mathrm{v}$ & & & $\mathrm{v}$ & \\
\hline \multirow[t]{9}{*}{4.} & \multirow[t]{9}{*}{ Mengerjakan Tugas } & workshop & & & & $\mathrm{v}$ & & & $\mathrm{v}$ & & & $\mathrm{v}$ & & \\
\hline & & R.305 & $\mathrm{v}$ & & & & & & & & & & & \\
\hline & & R.306 & & & $\mathrm{v}$ & & & & & & & & & \\
\hline & & R.309 & & & & & & & & & & & & \\
\hline & & Meja Beton & & & & & & & & & & & $\mathrm{v}$ & \\
\hline & & Kantin & & & $\mathrm{v}$ & & $\mathrm{v}$ & & & $\mathrm{v}$ & & & & \\
\hline & & Selasar Despro & & & & & & & & & $\mathrm{v}$ & & & $\mathrm{v}$ \\
\hline & & Selasar Workshop & & & & & & $\mathrm{v}$ & & & & & & \\
\hline & & Other : Ruang Baca & & $\mathrm{v}$ & & & & & & & & & & \\
\hline \multirow[t]{6}{*}{5.} & \multirow[t]{6}{*}{ Rapat Himpunan } & Kantin & & & & $\mathrm{v}$ & & & & & & & & \\
\hline & & Ruang HIMA & & & & & & & & & $\mathrm{v}$ & & & \\
\hline & & R.305 & & & & & $\mathrm{v}$ & & & & & & & \\
\hline & & R.308 & & & & & & $\mathrm{v}$ & & & & & & \\
\hline & & 3.309 & & & & & & & & $\mathrm{v}$ & & & & \\
\hline & & Lainnya & & & & & & & $\mathrm{v}$ & & & & & \\
\hline \multirow[t]{4}{*}{6.} & \multirow[t]{4}{*}{ Kegiatan Komunitas } & Selasar & $\mathrm{v}$ & & & & & $\mathrm{v}$ & & & $\mathrm{v}$ & & & \\
\hline & & workshop & & & & & $\mathrm{v}$ & & & $\mathrm{v}$ & & $\mathrm{v}$ & & \\
\hline & & Kantin & & & & $\mathrm{v}$ & & & & & & & $\mathrm{v}$ & \\
\hline & & Lainnya & & & & & & & $\mathrm{v}$ & & & & & $\mathrm{v}$ \\
\hline \multirow[t]{5}{*}{7.} & \multirow[t]{5}{*}{ Berkumpul angkatan } & Selasar Workshop & $\mathrm{v}$ & & & & & & & $\mathrm{v}$ & & $\mathrm{v}$ & & \\
\hline & & E-Bola Despro & & & & & & $\mathrm{v}$ & & & $\mathrm{v}$ & & & \\
\hline & & Kantin & & $\mathrm{v}$ & & $\mathrm{v}$ & & & & & & & & $\mathrm{v}$ \\
\hline & & Tribun / Meja Beton & & & $\mathrm{v}$ & & $\mathrm{v}$ & & $\mathrm{v}$ & & & & $\mathrm{v}$ & \\
\hline & & Lainnya & & & & & & & & & & & & \\
\hline \multirow[t]{4}{*}{8.} & \multirow{4}{*}{$\begin{array}{c}\text { Mengobrol } \\
\text { (kegiatan lain) }\end{array}$} & Kantin & $\mathrm{v}$ & & & $\mathrm{v}$ & & & & $\mathrm{v}$ & & & $\mathrm{v}$ & \\
\hline & & Workshop & & & & & & & & & & $\mathrm{v}$ & & \\
\hline & & Ruang Baca & & $\mathrm{v}$ & & & & $\mathrm{v}$ & & & $\mathrm{v}$ & & & \\
\hline & & Meja Beton & & & $\mathrm{v}$ & & $\mathrm{v}$ & & $\mathrm{v}$ & & & & & $\mathrm{v}$ \\
\hline
\end{tabular}

Keterangan :

Sering
Kadang-Kadang
Jarang

(Sumber : Observasi dan Kuisioner, 2019)

Mahasiswa angkatan 2015 adalah mahasiswa paling senior yang sedang tahap tugas akhir. Kegiatan lebih banyak bersifat mandiri, baik yang dilakukan di kampus maupun di luar kampus. Kepentingan mahasiswa angkatan 2015 ketika di kampus lebih pada kegiatan menemui dosen pembimbing untuk asistensi, koordinasi mata kuliah tugas akhir, serta kerja mandiri dengan kebutuhan akses wifi. Koordinasi dilakukan seminggu sekali, oleh karenanya mahasiswa 2015 memanfaatkan hari koordinasi mata kuliah Tugas Akhir sebagai kesempatan guna menemui dosen pembimbing untuk asistensi. Ruang 305, 206 dan selasar menjadi based place yang sering dikunjungi mahasiswa angkatan 2015. Keterikatan pada place tersebut karena aktivitas koordinasi mata kuliah, asistensi serta progres mandiri dalam penyelesaian mata kuliah satu satunya yang diambil, yaitu Tugas Akhir. Kemudahan mengakses wifi serta ketersediaan stop kontak menjadi pengikat keberadaan mahasiswa Tugas Akhir dalam progres mandiri.

Mahasiswa angkatan 2016 adalah mahasiswa tahun ketiga perkuliahan yang memiliki tugas memegang kepengurusan organisasi himpunan mahasiswa desain interior. Pada beban kurikulum, tahun ketiga merupakan puncak beban perkuliahan yang cukup berat. Terdapat beberapa mata kuliah perancangan yang dilakukan dalam satu semester. Sehingga mahasiswa dituntut untuk lebih banyak bekerja sistem studio (kuliah, asistensi dan kerja mandiri). 
Kebutuhan ruang besar untuk sistem studio tersebut diwadahi di ruang yang bersifat fleksibel, yaitu ruang perkuliahan yang memiliki batas/partisi antar ruang yang dapat diatur/fleksibel. Fleksibilitas luasan ruang untuk kegiatan studio sangat bermanfaat bagi mahasiswa angkatan 2016. Keterikatan pada ruang yang fleksibel tersebut diwadahi pada ruang 101 dan 102. Adapun kegiatan kepengurusan himpunan mahasiswa, membutuhkan ruang yang bersifat 'tanpa batas waktu'. Suatu ruangan yang tidak digunakan untuk kegiatan perkuliahan, yaitu kantin.

Mahasiswa angkatan 2017 merupakan mahasiswa tahun kedua dengan intensitas waktu perkuliahan yang masih relative padat, namun mulai mengikuti kegiatan kepengurusan himpunan. Keterikatan pada fasilitas di kampus, masih fokus pada kegiatan perkuliahan, yaitu kelas teori, studio dan asistensi. Kebersamaan dalam perkuliahan masih banyak dilakukan oleh mahasiswa angkatan 2017, sehingga keterikatan pada ruang atau fasilitas kampus tersentral/ mengumpul pada ruang yang sama, yaitu di ruang workshop. Keberadaan ruang dosen di area workshop merupakan keterikatan guna memudahkan mengumpulkan tugas serta asistensi yang terstruktur. Adapun kegiatan organisasi himpunan maupun komunitas mahasiswa interior, lebih bersifat membantu senior nya (angkatan 2016), sehingga kebutuhan berkumpul bersifat lebih santai yaitu di meja beton yang terletak di halaman luar.

Mahasiswa angkatan 2018 merupakan mahasiswa baru yang kegiatannya masih sepenuhnya untuk perkuliahan yang bersifat paket, sehingga belum terlibat dengan kegiatan organisasi himpunan mahasiswa. Untuk kegiatan perkuliahan paket tersebut, mahasiswa angkatan 2018 terkonsentrasi pada ruang dan fasilitas yang ada kaitannya dengan perkuliahan dengan mata kuliah yang harus diambil. Beberapa mata kuliah bersifat mata kuliah dasar umum, yang terselenggara di gedung jurusan lain. Keterikatan pada fasilitas tempat di kampus desain interior karena mata kuliah dasar kompetensi interior. Mobilitas mahasiswa baru ( angkatan 2018) pada mata kuliah dasar kompetensi interior diadakan pada ruang workshop. Bahkan untuk kegiatan yang bersifat komunitas juga diadakan di ruang workshop. Place bonding yang dilakukan mahasiswa angkatan 2018 lebih karena kebutuhan perkuliahan paket yang harus diambil bersama.

Berdasarkan pembahasan di atas, maka place bonding mahasiswa dalam penggunaan ruang sangat dipengaruhi oleh jenis mata kuliah (teori atau studio), jumlah/beban perkuliahan, perkuliahan paket bagi mahasiswa baru, kemudahan mengakses internet, fleksibilitas ruang, tempat berkumpul 'tanpa batas waktu', kegiatan komunitas mahasiswa serta organisasi himpunan mahasiswa.

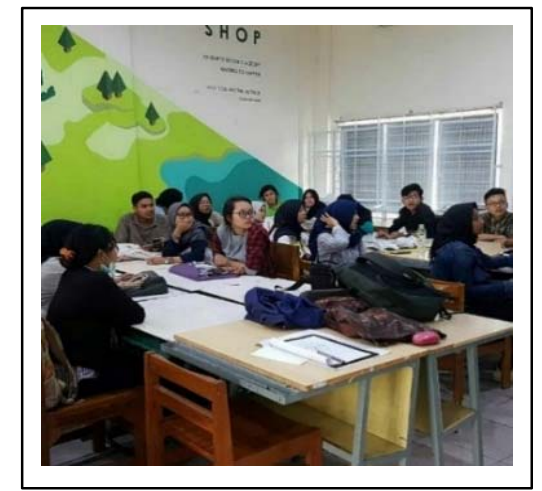

Gambar 1. Foto Kegiatan Perkuliahan Mahasiswa Sumber: Dokumentasi Peneliti (2019)

Tabel 2 berikut membahas tentang place bonding mahasiswa desain yang dikaitkan dengan intensitas/frekuensi disetiap detail aktivitas akademik maupun non-akademik. 


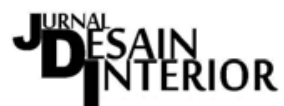

Vol. 4, No. 1, Juni 2019, pISSN 2527-2853, eISSN 2549-2985

Tabel 2. Intensitas Waktu Berkegiatan di Kampus Desain Interior

\begin{tabular}{|c|c|c|c|c|c|c|c|c|c|c|c|c|c|c|}
\hline \multirow{5}{*}{$\begin{array}{c}\text { No } \\
1\end{array}$} & \multirow{5}{*}{$\begin{array}{c}\text { Kegiatan } \\
\begin{array}{c}\text { Kegiatan Belajar Mengajar ( } \\
\text { Jam Kuliah) }\end{array}\end{array}$} & \multirow{3}{*}{$\begin{array}{c}\begin{array}{c}\text { Keterangan Satuan } \\
\text { Kegiatan }\end{array} \\
5 \text { hari }\end{array}$} & \multicolumn{12}{|c|}{ Ruang } \\
\hline & & & \multicolumn{3}{|c|}{2015} & \multicolumn{3}{|c|}{2016} & \multicolumn{3}{|c|}{2017} & \multicolumn{3}{|c|}{2018} \\
\hline & & & & & $\mathrm{v}$ & $\mathrm{v}$ & & & & $\mathrm{v}$ & & $\mathrm{v}$ & & \\
\hline & & 4 hari & & $\mathrm{v}$ & & & $\mathrm{V}$ & & $\mathrm{v}$ & & & & & $\mathrm{V}$ \\
\hline & & $<4$ hari & $\mathrm{V}$ & & & & & $\mathrm{V}$ & & & & & $\mathrm{v}$ & \\
\hline \multirow[t]{3}{*}{2.} & \multirow[t]{3}{*}{ Jumlah SKS } & $10-15$ sks & $\mathrm{V}$ & & & & & $\mathrm{V}$ & & & $\mathrm{V}$ & & & \\
\hline & & $16-20$ sks & & $\mathrm{V}$ & & & $\mathrm{V}$ & & $\mathrm{V}$ & & & $\mathrm{v}$ & & \\
\hline & & $>20$ sks & & & $\mathrm{V}$ & $\mathrm{V}$ & & & & $\mathrm{V}$ & & & & \\
\hline \multirow[t]{3}{*}{3.} & \multirow{3}{*}{$\begin{array}{l}\text { Jumlah Mata kuliah yang tidak } \\
\text { menggunakan kelas Desain }\end{array}$} & $>3$ matkul & & $\mathrm{V}$ & & & $\mathrm{V}$ & & & $\mathrm{V}$ & & & $\mathrm{v}$ & \\
\hline & & 3 matkul & & & $\mathrm{V}$ & & & $\mathrm{V}$ & & & $\mathrm{V}$ & $\mathrm{V}$ & & \\
\hline & & $<3$ matkul & $\mathrm{V}$ & & & $\mathrm{V}$ & & & $\mathrm{V}$ & & & & & $\mathrm{V}$ \\
\hline \multirow[t]{3}{*}{4.} & \multirow[t]{3}{*}{ Asistensi Diluar Jam Kuliah } & Sering & $\mathrm{V}$ & & & & & $\mathrm{V}$ & & & & & & $\mathrm{V}$ \\
\hline & & Tidak terlalu sering & & $\mathrm{V}$ & & & $\mathrm{V}$ & & & & & $\mathrm{V}$ & & \\
\hline & & Jarang & & & $\mathrm{V}$ & $\mathrm{V}$ & & & & & & & $\mathrm{v}$ & \\
\hline \multirow[t]{3}{*}{5.} & \multirow{3}{*}{$\begin{array}{l}\text { Mengumpulkan tugas diluar } \\
\text { Jam Kuliah }\end{array}$} & Sering & $\mathrm{V}$ & & & & $\mathrm{V}$ & & & & $\mathrm{V}$ & & & \\
\hline & & Tidak terlalu sering & & $\mathrm{V}$ & & $\mathrm{V}$ & & & $\mathrm{v}$ & & & $\mathrm{V}$ & & \\
\hline & & Jarang & & & $\mathrm{V}$ & & & $\mathrm{V}$ & & $\mathrm{V}$ & & & $\mathrm{v}$ & \\
\hline \multirow[t]{3}{*}{6.} & \multirow{3}{*}{$\begin{array}{l}\text { Memanfaatkan Kelas Kosong } \\
\text { untuk mengerjakan tugas }\end{array}$} & Sering & $\mathrm{V}$ & & & & & $\mathrm{V}$ & & $\mathrm{V}$ & & & & $\mathrm{V}$ \\
\hline & & Tidak terlalu sering & & & $\mathrm{V}$ & & $\mathrm{V}$ & & $\mathrm{V}$ & & & $\mathrm{V}$ & & \\
\hline & & Jarang & & $\mathrm{v}$ & & $\mathrm{V}$ & & & & $\mathrm{V}$ & & & $\mathrm{v}$ & \\
\hline 7. & Mengerjakan tugas di Kampus & Sering Di Kampus & & $\mathrm{V}$ & & & $\mathrm{V}$ & & & $\mathrm{V}$ & & $\mathrm{V}$ & & \\
\hline & & Sering di Luar Kampus & $\mathrm{v}$ & & & $\mathrm{V}$ & & & $\mathrm{V}$ & & & & & \\
\hline 8. & Tugas yang mengharuskan & Tugas Individu & & $\mathrm{V}$ & & $\mathrm{V}$ & & & & & $\mathrm{V}$ & & & $\mathrm{V}$ \\
\hline & dikerjakan di Kampus & Tugas Kelompok & & & $\mathrm{V}$ & & & $\mathrm{V}$ & & $\mathrm{V}$ & & & & \\
\hline & & $\begin{array}{l}\text { Tugas Individu dan } \\
\text { Kelompok }\end{array}$ & $\mathrm{v}$ & & & & $\mathrm{v}$ & & $\mathrm{v}$ & & & $\mathrm{v}$ & & \\
\hline 9 & Mengikuti Kegiatan Himpunan & Selalu & & & & & & $\mathrm{V}$ & & $\mathrm{V}$ & & & & \\
\hline & & Normal & & & & $\mathrm{V}$ & & & $\mathrm{v}$ & & & & & \\
\hline & & Jarang & & & & & $\mathrm{V}$ & & & & $\mathrm{V}$ & & & \\
\hline 10 & Preferensi Rapat himpunan & Di kampus & & & & $\mathrm{V}$ & & & $\mathrm{v}$ & & & & & \\
\hline & & Di luar kampus & & & & & $\mathrm{V}$ & & & $\mathrm{V}$ & & & & \\
\hline 11 & Mengikuti kegiatan komunitas & Sering & & $\mathrm{V}$ & & & & $\mathrm{V}$ & & $\mathrm{V}$ & & $\mathrm{V}$ & & \\
\hline & & Tidak terlalu sering & & & $\mathrm{V}$ & & $\mathrm{V}$ & & $\mathrm{v}$ & & & & $\mathrm{v}$ & \\
\hline & & Jarang & $\mathrm{v}$ & & & $\mathrm{V}$ & & & & & & & & $\mathrm{v}$ \\
\hline 12 & Waktu kegiatan komunitas & 1 jam & $\mathrm{V}$ & & & & $\mathrm{V}$ & & & & $\mathrm{V}$ & & & $\mathrm{V}$ \\
\hline & & 2 jam & & & $\mathrm{V}$ & $\mathrm{V}$ & & & $\mathrm{v}$ & & & $\mathrm{V}$ & & \\
\hline & & 3 jam & & $\mathrm{V}$ & & & & $\mathrm{V}$ & & $\mathrm{V}$ & & & $\mathrm{v}$ & \\
\hline 13 & Mengikuti kegiatan angkatan & Sering & $\mathrm{v}$ & & & & $\mathrm{V}$ & & & $\mathrm{V}$ & & $\mathrm{V}$ & & \\
\hline & & Normal & & $\mathrm{V}$ & & $\mathrm{V}$ & & & $\mathrm{v}$ & & & & $\mathrm{v}$ & \\
\hline & & Jarang & & & $\mathrm{V}$ & & $\mathrm{V}$ & & & & $\mathrm{V}$ & & & $\mathrm{V}$ \\
\hline 14 & $\begin{array}{c}\text { Angkatan melakukan sebuah } \\
\text { kegiatan di Kampus }\end{array}$ & Sering & & & & & & $\mathrm{V}$ & & $\mathrm{v}$ & & & $\mathrm{v}$ & \\
\hline & & Normal & & & & $\mathrm{V}$ & & & $\mathrm{V}$ & & & $\mathrm{V}$ & & \\
\hline & & Jarang & & & & & $\mathrm{V}$ & & & & $\mathrm{V}$ & & & $\mathrm{v}$ \\
\hline 15 & Melakukan kegiatan lain & Mengerjakan tugas & $\mathrm{v}$ & & & $\mathrm{V}$ & & & & $\mathrm{V}$ & & & $\mathrm{v}$ & \\
\hline & & Rapat & & & $\mathrm{V}$ & & & $\mathrm{V}$ & $\mathrm{V}$ & & & & & \\
\hline & & $\begin{array}{c}\text { Sekedar mengobrol } \\
\text { Bersama teman }\end{array}$ & & $\mathrm{v}$ & & & $\mathrm{V}$ & & & & & & & $\mathrm{v}$ \\
\hline & & Kegiatan komunitas & & & & & & & & & $\mathrm{V}$ & $\mathrm{v}$ & & \\
\hline & & & & & & & & & & & & & & \\
\hline & Sering & -Kadang & & 100 & & & & & & & & & & \\
\hline
\end{tabular}

Sumber: Observasi dan Kusioner (2019)

Karena sudah memasuki semester terakhir, maka mahasiswa angkatan 2015 sudah tidak terikat dengan jadwal perkuliahan dan kegiatan kemahasiswaan. Kegiatan yang dilakukan di kampus hanya berkaitan dengan Tugas Akhir, yaitu koordinasi, asistensi dengan pembimbing serta bekerja mandiri. Mahasiswa angkatan 2015 juga tidak jarang mengerjakan Tugas Akhir/bekerja mandiri di luar kampus desain. Karena sudah tidak mengikuti himpunan dan komunitas, maka mahasiwa angkatan 2015 jarang sekali berkepentingan dengan fasilitas 
fasilitas lain di kampus. Sementara itu, terjadi kondisi yang sebalinya pada mahasiswa angkatan 2016. Intensitas keterikatan di kampus relatif tinggi yaitu 5 hari berturut turut. Tidak hanya perkuliahan yang rata rata memiliki beban lebih dari 20 sks/mahasiswa, namun juga kegiatan organisasi himpunan serta komunitas.

Selanjutnya, mahasiswa angkatan 2017 termasuk angkatan yang berada di posisi antara beban perkuliahan dengan pengenalan organisasi. Beban perkuliahan masih mendominasi, karena belum terlibat langsung pada kepengurusan organisasi. Pengenalan organisasi dan komunitas menjadi keterikatan mahasiswa angkatan 2017 pada kampus desain. Kondisi yang paling kuat identitas keteriakatan pada kampus desain, adalah mahasiswa angkatan 2018. Perkuliah pengenalan desain menuntut mahasiswa bertatap muka secara rutin dengan dosen pembimbing. Bimbingan atau asistensi bersifat individu/ kelompok saat perkuliahan berlangsung, jarang dilakukan di luar jam perkuliahan. Mahasiswa angkatan 2018 belum mengikuti organisasi himpunan mahasiswa desain, namun sudah diijinkan untuk berkegiatan komunitas. Terkait kegiatan angkatan, hampir semua mahasiswa 2018 sering mengikuti kegiatan yang diadakan oleh angkatan mereka sendiri seperti Interior Project, KPP TD dan lainlain. Kegiatan lainnya yang membuat angkatan 2018 sering berada di area kampus desain interior adalah karena kebutuhan mengerjakan tugas atau sekedar mengobrol bersama temannya.

Berdasarkan pembahasan di atas (Tabel 2), maka keterikatan mahasiswa pada kampus desain dibedakan atas intensitas kehadirannya berdasarkan beban perkuliahan, kegiatan organisasi, kegiatan komunitas serta kegiatan per angkatan

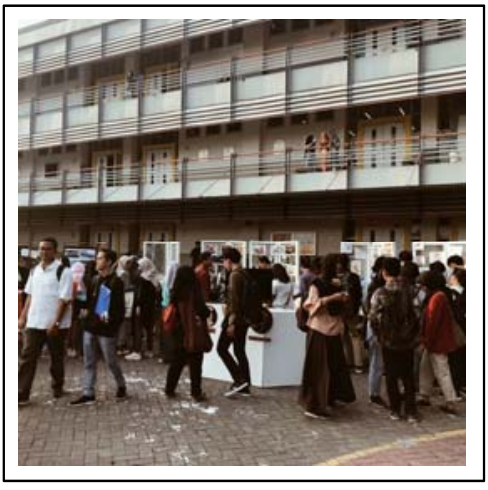

Gambar 2. Foto Kegiatan Komunitas Sumber: Dokumentasi Peneliti (2019)

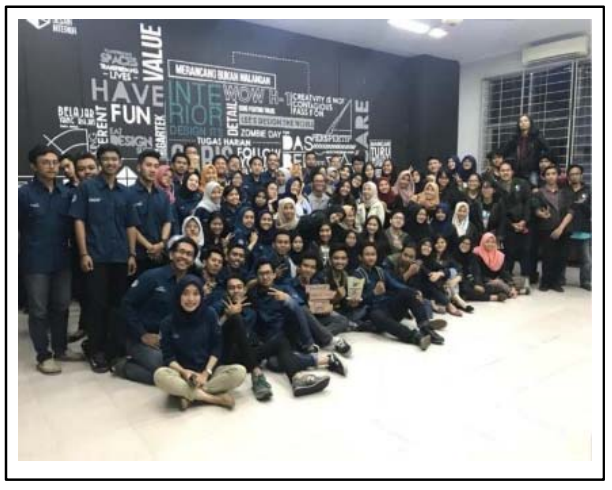

Gambar 3. Foto Kegiatan Himpunan Sumber: Dokumentasi Peneliti (2019)

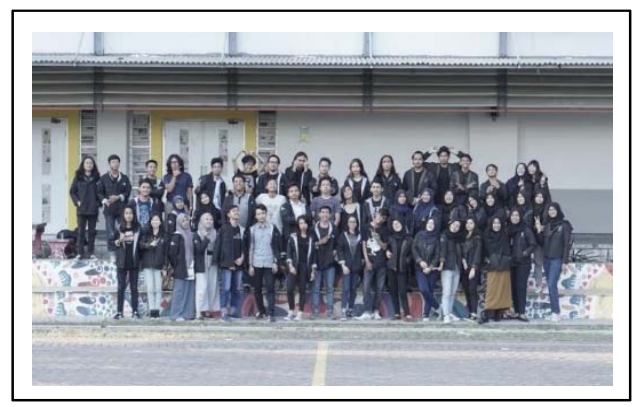

Gambar 4. Foto Kegiatan Angkatan Sumber: Dokumentasi Peneliti (2019)

Place bonding mahasiswa desain adalah hal yang spesifik. Selain karena aktivitas desain, terdapat sign yang menjadi identitas place bonding. 
Tabel 3. Sign mahasiswa Desain Interior Sebagai Identitas Pembentuk Place Bonding

\begin{tabular}{|c|c|c|c|c|c|c|c|c|c|c|c|c|c|c|}
\hline \multirow{3}{*}{$\begin{array}{c}\text { No } \\
1\end{array}$} & \multirow{2}{*}{\multicolumn{2}{|c|}{ Tanda/sign }} & \multicolumn{12}{|c|}{ Tahun / Angkatan Mahasiswa } \\
\hline & & & \multicolumn{3}{|c|}{2015} & \multicolumn{3}{|c|}{2016} & \multicolumn{3}{|c|}{2017} & \multicolumn{3}{|c|}{2018} \\
\hline & \multirow{5}{*}{$\begin{array}{c}\text { Barang penting } \\
\text { yang dibawa ke } \\
\text { kelas }\end{array}$} & tabung & & & & & & $\mathrm{V}$ & & & $\mathrm{V}$ & & $\mathrm{v}$ & \\
\hline & & laptop & $\mathrm{v}$ & & & $\mathrm{v}$ & & & $\mathrm{v}$ & & & & & $\mathrm{V}$ \\
\hline & & pewarna & & & $\mathrm{V}$ & & & & & & & & & \\
\hline & & Buku catatan & & $\mathrm{V}$ & & & $\mathrm{V}$ & & & $\mathrm{V}$ & & & & \\
\hline & & Kertas Gambar & & & & & & & & & & $\mathrm{v}$ & & \\
\hline \multirow[t]{4}{*}{2} & \multirow{4}{*}{$\begin{array}{l}\text { Bentuk barang } \\
\text { asistensi }\end{array}$} & Kertas BC & & & $\mathrm{V}$ & & & & & & & $\mathrm{V}$ & & \\
\hline & & Kertas HVS & $\mathrm{V}$ & & & & $\mathrm{V}$ & & & $\mathrm{V}$ & & & & $\mathrm{V}$ \\
\hline & & Karya 3D & & & & & & $\mathrm{v}$ & & & $\mathrm{V}$ & & $\mathrm{V}$ & \\
\hline & & Soft file & & $\mathrm{V}$ & & $\mathrm{V}$ & & & $\mathrm{V}$ & & & & & \\
\hline \multirow[t]{7}{*}{3} & \multirow[t]{7}{*}{ Jenis pakaian } & kemeja & & & & & $\mathrm{v}$ & & & $\mathrm{v}$ & & $\mathrm{V}$ & & \\
\hline & & kaos & $\mathrm{v}$ & & & $\mathrm{v}$ & & & $\mathrm{v}$ & & & & $\mathrm{v}$ & \\
\hline & & Jaket/outter & & & $\mathrm{v}$ & & $\mathrm{V}$ & & & & & & & \\
\hline & & Celana jeans & & $\mathrm{V}$ & & $\mathrm{v}$ & & & & & & & & \\
\hline & & Celana selain jeans & & & & & & & & $\mathrm{v}$ & & & & \\
\hline & & Rok & & & & & & & & & & & & \\
\hline & & Baju terusan & & & & & & $\mathrm{v}$ & & & $\mathrm{V}$ & & & $\mathrm{V}$ \\
\hline \multirow[t]{4}{*}{4} & \multirow[t]{4}{*}{ Jenis Alas Kaki } & Sepatu & $\mathrm{V}$ & & & $\mathrm{v}$ & & & $\mathrm{v}$ & & & $\mathrm{V}$ & & \\
\hline & & Flatshoes & & $\mathrm{v}$ & & & $\mathrm{v}$ & & & $\mathrm{V}$ & & & $\mathrm{V}$ & \\
\hline & & Sepatu Sandal & & & $\mathrm{V}$ & & & & & & $\mathrm{V}$ & & & \\
\hline & & Sandal & & & & & & $\mathrm{V}$ & & & & & & $\mathrm{V}$ \\
\hline \multirow[t]{5}{*}{5} & \multirow{5}{*}{$\begin{array}{l}\text { Melakukan } \\
\text { kegiatan }\end{array}$} & Sendiri & & $\mathrm{V}$ & & & $\mathrm{v}$ & & & & $\mathrm{V}$ & & & $\mathrm{V}$ \\
\hline & & Berdua & & & & & & & & & & & $\mathrm{v}$ & \\
\hline & & 3-5 orang & & & & $\mathrm{v}$ & & & $\mathrm{v}$ & & & $\mathrm{V}$ & & \\
\hline & & $2-5$ orang & $\mathrm{V}$ & & & & & & & & & & & \\
\hline & & Bersama $>5$ orang & & & $\mathrm{V}$ & & & $\mathrm{V}$ & & $\mathrm{V}$ & & & & \\
\hline \multirow[t]{4}{*}{6} & \multirow{4}{*}{$\begin{array}{l}\text { Penampilan } \\
\text { Laki-Laki }\end{array}$} & Rambut Panjang & & & $\mathrm{v}$ & & $\mathrm{v}$ & & & $\mathrm{V}$ & & & $\mathrm{v}$ & \\
\hline & & Rambut Pendek & $\mathrm{v}$ & & & $\mathrm{v}$ & & & $\mathrm{v}$ & & & $\mathrm{v}$ & & \\
\hline & & Botak & & & & & & $\mathrm{V}$ & & & $\mathrm{V}$ & & & $\mathrm{V}$ \\
\hline & & Rambut diwarna & & $\mathrm{V}$ & & & & $\mathrm{V}$ & & & & & & \\
\hline 7 & Penampilan & Berkerudung & $\mathrm{V}$ & & & $\mathrm{V}$ & & $\mathrm{v}$ & $\mathrm{V}$ & & & $\mathrm{V}$ & & \\
\hline & Perempuan & Tidak berkerudung & & $\mathrm{V}$ & & & $\mathrm{v}$ & & & $\mathrm{V}$ & & & $\mathrm{V}$ & \\
\hline & & $\begin{array}{l}\text { Tidak berkerudung dan } \\
\text { diwarna }\end{array}$ & & & $\mathrm{v}$ & & & $\mathrm{v}$ & & & $\mathrm{V}$ & & & $\mathrm{V}$ \\
\hline 8 & Angkatan yang & 2015 & & & $\mathrm{~V}$ & & & & & & & & & $\mathrm{~V}$ \\
\hline & paling sering & 2016 & $\mathrm{v}$ & & & $\mathrm{v}$ & & & $\mathrm{v}$ & & & & $\mathrm{V}$ & \\
\hline & terlihat di & 2017 & & $\mathrm{~V}$ & & & $\mathrm{v}$ & & & $\mathrm{V}$ & & $\mathrm{v}$ & & \\
\hline & kampus & 2018 & & & & & & $\mathrm{~V}$ & & & $\mathrm{~V}$ & & & \\
\hline 9 & Aturan berpakai & Tidak boleh pakai kaos & & & & & & & & & $\mathrm{V}$ & & $\mathrm{V}$ & \\
\hline & saat jam kuliah & Tidak boleh pakai topi & & & & & & & & & & & & $\mathrm{V}$ \\
\hline & & Harus pake sepatu & $\mathrm{v}$ & & & $\mathrm{v}$ & & & & $\mathrm{V}$ & & & & \\
\hline & & Bebas rapih dan sopan & & $\mathrm{V}$ & & & $\mathrm{V}$ & & $\mathrm{v}$ & & & $\mathrm{V}$ & & \\
\hline & & Tidak boleh pake jaket & & & $\mathrm{V}$ & & & $\mathrm{V}$ & & & & & & \\
\hline 10 & Aturan & Tidak boleh pakai kaos & & & $\mathrm{v}$ & & & & & & $\mathrm{v}$ & & & \\
\hline & berpakaian & Tidak boleh pakai topi & & & & & & $\mathrm{V}$ & & & & & & \\
\hline & diluar jam & Harus pake sepatu & & $\mathrm{v}$ & & & & & & & & & $\mathrm{v}$ & \\
\hline & kuliah & Bebas rapih dan sopan & $\mathrm{v}$ & & & $\mathrm{v}$ & & & $\mathrm{v}$ & & & $\mathrm{V}$ & & \\
\hline & & Tidak ada aturan & & & & & $\mathrm{V}$ & & & $\mathrm{V}$ & & & & $\mathrm{V}$ \\
\hline
\end{tabular}


Berdasarkan Tabel 3 di atas mahasiswa angkatan 2015 memiliki identitas utama hanya membawa laptop saat hadir di kampus. Data Tugas Akhir dikerjakan dan diasistensikan dalam bentuk softfile. Kehadiran yang hanya satu hingga 2 kali dalam seminggu cukup menjadi identitas sebagai mahasiswa tingkat akhir, ditunjang penampilan pakaian, rambut serta alas kaki yang cenderung rapi dan resmi. Mobilitas tidak terlalu tinggi, sehingga jarang nampak menggunakan jaket/outter.

Identitas di atas sangat berbeda dengan mahasiswa angkatan 2016. Mobilitas atau aktivitas yang tinggi, menyebabkan penampilan cenderung santai, misalnya memakai kaos dan celana jeans, bahkan dilengkapi jaket. Kondisi yang hampir serupa pada mahsiswa angkatan 2017, benda yang paling penting dibawa adalah laptop dan buku catatan. Tabung sudah masuk pada barang yang paling jarang dibawa. Sedangkan untuk tugas, lebih banyak dalam bentuk softfile dan paling sedikit dalam bentuk 3D. Karena tidak ada larangan memakai kaos, mahasiswa desain interior dari semua angkatan memilih untuk memakainya, kecuali ketika masuk pada kelas yang dosennya melarang hal tesebut. Untuk mahasiswa laki-laki, paling banyak berambut cepak, disusul rambut panjang, dan hampir tidak ada yang gundul. Mahasiswa perempuan lebih banyak memakai kerudung dan hampir tidak ada yang rambutnya dicat warna.

Berbeda dengan angkatan diatasnya, 2018 lebih sering membawa kertas gambar saat kegiatan perkuliahan karena tugas-tugas mereka masih banyak yang harus menggambar manual di kertas, jarang dari mereka yang menggunakan laptop. Bentuk barang asistensi 2018 pun masih banyak yang menggunakan kertas BC. Angkatan 2018 lebih sering terlihat di kampus mengenakan kemeja atau kaos, jarang sekali yang memakai baju terusan, alas kaki pun ratarata memakai sepatu dan flatshoes Hampir semua mahasiswa laki-lakin dari angkatan 2018 berambut pendek dan tidak diwarna, tapi terdapat beberapa yang berambut Panjang. Sementara penampilan mahasiswi perempuan lebih banyak yang berkerudung dibanding yang tidak. Angkatan 2018 juga lebih sering melakukan kegiatan secara berkelompok 3-5 orang, jarang mereka melakukan sebuah kegiatan seorang diri.

Berdasarkan pembahasan sign identitas di atas, maka disimpulkan bahwa mahasiswa angkatan 2015, 2016, dan 2017, memiliki identitas barang bawaan laptop, sedangkan untuk mahasiswa baru, yakni angkatan 2018, kertas gambar merupakan hal yang dominan. Mahasiswa angkatan 2018 masih mengawali tugas-tugasnya dalam bentuk sketsa dalam kertas. Untuk penampilan, angkatan 2015, 2016, dan 2017 cenderung memakai kaos untuk ke kampus. Sedangkan mahasiswa angkatan 2018 masih mempertahankan kemeja sebagai pakaian mereka. Persamaan dari keempat angkatan adalah sama-sama menggunakan sepatu sebagai alas kaki. Mahasiswa angkatan 2018 paling jelas dan dominan identitasnya. Hal tersebut merupakan tanda proses adaptasi menjadi mahasiswa desain, serta karakter jenis tugas mata kuliah mahasiwa baru yang spesifik.

\section{KESIMPULAN}

Hasil penelitian menunjukkan bahwa place bonding/keterikatan mahasiswa Desain Interior ITS dengan kampusnya paling dipengaruhi oleh karakter pembeda di setiap angkatan, karena pada setiap angkatan memiliki intensitas kegiatan yang berbeda. Berdasarkan pembahasan Tabel 1, 2, dan 3 disimpulkan bahwa angkatan 2015 memiliki keterikatan paling kecil, dikarenakan hanya mengerjakan tugas akhir perkuliahan, di mana jumlah SKS (Satuan Kredit Semester) paling sedikit dibanding 3 angkatan lainnya. Mereka juga tidak lagi mengikuti kegiatan angkatan, himpunan, maupun komunitas.

Adapun yang memiliki keterikatan paling besar adalah mahasiswa angkatan 2016. Mahasiswa angkatan ini memiliki beban tidak hanya perkuliahan, namun juga organisasi dan komunitas. Untuk kegiatan belajar mengajar paling banyak dilakukan di kelas workshop 
(Ruang 101 dan 102), karena perkuliahan banyak menggunakan sistem studio, sehingga membutuhkan ruang yang fleksibel pengaturannya. Jenis mata kuliah studio, bagi mahasiswa angkatan 2016 menjadi beban terberat yang dominan dibanding angkatan lain.

Identitas mahasiswa desain interior sebagai bentuk keterikatan terhadap desain ditandai dengan kebutuhan peralatan laptop dan kertas gambar. Penampilan cenderung rapi yaitu dengan menggunakan kemeja/kaos, celana jean dan sepatu.

\section{DAFTAR PUSTAKA}

Jattmiko, Agus. (2016). Sense of Place dan Social Anxiety bagi Mahasiswa Baru Pendatang. Lampung: Dosen Fakultas Tarbiyah dan Keguruan, IAIN Raden Intan Lampung

Nurfitriana, Pipit. (2016). Penyesuaian Diri pada Mahasiswa Tahun Pertama di Fakultas Psikologi Universitas Muhammadiyah Surakarta. Surakarta: Universitas Muhammadiyah Surakarta.

Nurhijah. (2015). Kerangka Penelitian Place Attatchment pada Tempat-Tempat Bernilai Budaya. Bandung: Institut Teknologi Bandung.

Nor Zarifah Maliki. (2016). Place Attatchment and Place Indentity: Undergraduate Student's Place Bonding on Campus. China: Colleger of Architecture and Civil Enginering, Hebei University, Baoding City, and Malaysia: School of Housing, Buulding, and Planning, University Sains Malaysia

Qazimi, Shukran. (2014). Sense of Place and Place Identity. Albania: Epoka University, Faculty of Civil Engineering and Architecture Department of Architecture Tirana. 
Susy Budi Astuti, Friday Yaumus S., Lisani Husna, Elvira Pramesvari

Place Bonding on Campus Interior Design ITS: Attachment and Identity 